Article

\title{
Catalytic Hydrotreatment of Microalgae Biocrude from Continuous Hydrothermal Liquefaction: Heteroatom Removal and Their Distribution in Distillation Cuts
}

\author{
Muhammad Salman Haider, Daniele Castello®, Karol Michal Michalski, \\ Thomas Helmer Pedersen $(\mathbb{D}$ and Lasse Aistrup Rosendahl * \\ Department of Energy Technology, Aalborg University, Pontoppidanstræde 111, 9220 Aalborg Øst, Denmark; \\ mush@et.aau.dk (M.S.H.); dac@et.aau.dk (D.C.); karol.michal.michalski@gmail.com (K.M.M.); \\ thp@et.aau.dk (T.H.P.) \\ * Correspondence: lar@et.aau.dk; Tel.: +45-9940-9263
}

Received: 27 October 2018; Accepted: 26 November 2018; Published: 1 December 2018

check for updates

\begin{abstract}
To obtain drop-in fuel properties from 3rd generation biomass, we herein report the catalytic hydrotreatment of microalgae biocrude, produced from hydrothermal liquefaction (HTL) of Spirulina. Our contribution focuses on the effect of temperature, initial $\mathrm{H}_{2}$ pressure, and residence time on the removal of heteroatoms $(\mathrm{O}$ and $\mathrm{N})$ in a batch hydrotreating setup. In contrast to common experimental protocols for hydrotreating at batch scale, we devised a set of two-level factorial experiments and studied the most influential parameters affecting the removal of heteroatoms. It was found that up to $350{ }^{\circ} \mathrm{C}$, the degree of deoxygenation (de-O) is mainly driven by temperature, whereas the degree of denitrogenation (de-N) also relies on initial $\mathrm{H}_{2}$ pressure and temperature-pressure interaction. Based on this, complete deoxygenation was obtained at mild operating conditions $\left(350{ }^{\circ} \mathrm{C}\right)$, reaching a concurrent $47 \%$ denitrogenation. Moreover, three optimized experiments are reported with 100\% removal of oxygen. In addition, the analysis by GC-MS and Sim-Dis gives insight to the fuel quality. The distribution of heteroatom $\mathrm{N}$ in lower $\left(<340^{\circ} \mathrm{C}\right)$ and higher $\left(>340^{\circ} \mathrm{C}\right)$ fractional cuts is studied by a fractional distillation unit following ASTM D-1160. Final results show that $63-68 \%$ of nitrogen is concentrated in higher fractional cuts.
\end{abstract}

Keywords: hydrothermal liquefaction (HTL); Spirulina; hydroprocessing; hydrotreating; upgrading; hydrodeoxygenation (HDO); hydrodenitrogenation (HDN); fractional distillation; drop-in biofuels; nitrogen distribution

\section{Introduction}

Unprecedented climate shift and brisk depletion of conventional resources have raised socioeconomic and environmental concerns; thus the pursuit of clean, independent and alternative renewable and sustainable commercialized solutions for fuels has been expedited [1]. Fuels produced from so-called 2nd and 3rd generation biomass feedstocks, such as sewage sludge and microalgae, offer the advantage of a potentially favorable carbon footprint and a lower risk of negative indirect land use change (ILUC) [2-4].

Microalgae have been identified as an attractive energy source for the production of biofuels due to their ability to accumulate relatively large amount of lipids along with carbohydrates, and proteins [5,6]. Microalgae show higher photosynthetic efficiencies compared to terrestrial plants which could be beneficial in terms of environmental impact [7]. High growth rates and non-competition with arable land and fresh water resources, triggered escalating interests to convert microalgae into liquid 
fuels, which engage researchers to develop environment-friendly methods with remarkable potential roots for mass production $[8,9]$.

Out of all available energy valorization techniques at our disposal, hydrothermal liquefaction (HTL) is considered as one of the most promising technologies for the production of biocrude oil, due to its advantages in rapid reaction, using all types of wet or dry feedstocks with no lipid-content restriction [10-12]. Recent techno-economic analyses and life cycle assessments on the conversion of microalgae into liquid fuels show that HTL has lower GHG emissions and higher economic potential, with a better energy return on investment as compared to conventional lipid extraction and transesterification technologies [13-16].

At temperatures around $300-420{ }^{\circ} \mathrm{C}$ and pressure above the saturation pressure of water the HTL process produces a viscous and energetically dense black liquid usually referred as biocrude. This biocrude contains $~ 10-15$ wt. \% of heteroatoms (primarily $\mathrm{O}$ and $\mathrm{N}$ ) with a high heating value (HHV) of $\sim 30-38 \mathrm{MJ} / \mathrm{kg}[17,18]$. Biocrude as such cannot be directly utilized in the transportation sector. To produce fungible on-specification transportation fuel, further upgrading processes such as deoxygenation, denitrogenation, etc. are required. Over the years, researchers have investigated both heterogeneous and homogeneous in-situ catalysts to achieve improved bio-diesel $[19,20]$. Catalytic upgrading of biocrude through hydroprocessing is the most promising pathway for the conversion of polar compounds into hydrocarbon-rich mixtures [21]. During hydroprocessing, undesirable components such as metals, oxygen, sulfur, nitrogen, olefins, and aromatics are removed from biocrude by selectively reacting them in the presence of a heterogeneous catalyst, at relatively high pressure (30-170 bar $\mathrm{H}_{2}$ ) and at high temperature $300-450{ }^{\circ} \mathrm{C}$ [22].

Several studies on the hydrotreating of algal biocrudes are documented in the open literature. Biller et al. [21] investigated the hydroprocessing of biocrude obtained from Chlorella microalgae, by using sulfided CoMo and NiMo catalysts at $350{ }^{\circ} \mathrm{C}$ and $405{ }^{\circ} \mathrm{C}$, with an initial $\mathrm{H}_{2}$ pressure between 60-66 bar and a residence time of $2 \mathrm{~h}$. Relatively low yields (41-69\%) were observed at high temperature, and 86 and $91 \%$ reduction of $\mathrm{O}$, along with 60 and $55 \%$ of reduction of $\mathrm{N}$, were obtained with NiMo and CoMo catalyst, respectively. Both catalysts showed no difference in their catalytic activity at batch scale; furthermore, after pentane extraction the oil analysis indicated that the majority of remaining $\mathrm{O}$ is contained in high molecular weight compounds, while no adequate reduction of nitrogen was achieved. Bai et al. [23] carried out the catalytic hydrothermal processing of biocrude in the presence of 15 different catalysts in a batch reactor. By using a combination of $\mathrm{Ru} / \mathrm{C}$ and Raney Ni catalyst they were able to obtain 2 wt. $\% \mathrm{O}$ and $2 \mathrm{wt} . \% \mathrm{~N}$ with a yield of $77 \%$. Duan et al. [24] observed, $90 \%$ of $\mathrm{O}$ and $59 \%$ of $\mathrm{N}$ removal after the catalytic hydrothermal upgrading of microalgae biocrude by using a mixture of $\mathrm{Ru} / \mathrm{C}$ and $\mathrm{Mo}_{2} / \mathrm{C}$ as catalyst at $400{ }^{\circ} \mathrm{C}$ for $4 \mathrm{~h}$. $\mathrm{Li}$ and Savage [25] explored the degree of deoxygenation and denitrogenation by using an acidic cracking catalyst (HZSM-5) in the presence of $\mathrm{H}_{2}$ at 400,450 and $500{ }^{\circ} \mathrm{C}$. They found that the upgraded oil yield was reduced from 75 to $42 \%$ as the temperature increases. Elliott et al. [26] reported the continuous hydrotreatment of biocrudes from four different microalgae in a bench-scale trickle bed reactor in the presence of sulfided $\mathrm{Co}-\mathrm{Mo} / \gamma-\mathrm{Al}_{2} \mathrm{O}_{3}$ catalyst at $405{ }^{\circ} \mathrm{C}$ and operating pressure of $136 \mathrm{bar}$. They obtained oil yields of $80-85 \%$ with final $\mathrm{O}$ and $\mathrm{N}$ levels of $\sim 1$ and $\sim 0.1 \mathrm{wt} . \%$, respectively. However, the authors also highlighted the difficulty to compare results from continuous and batch system, because the products from batch system are equilibrium limited.

Although these studies featured hydrotreating tests in different process conditions, the overall effect of temperature, pressure and residence time on heteroatom removal has not been systematically evaluated. A thorough investigation could be of great importance to understand which parameters, or combinations thereof, influence the performance of the process. In the current work, a two-level factorial experimental design was developed and the HTL hydrotreatment of microalgae biocrude, obtained from Spirulina was evaluated. The effect of temperature, $\mathrm{H}_{2}$ pressure, and residence time on the hydrodeoxygenation (HDO), hydrodenitrogenation (HDN), and hydrogen consumption was discussed. In this evaluation, a maximum temperature of initially $350{ }^{\circ} \mathrm{C}$, then $400{ }^{\circ} \mathrm{C}$ was considered, 
which differs from the previous literature (e.g., $[21,23,26])$. Following this analysis, three confirmatory experiments were performed at high temperatures to understand the significance of heteroatom removal. Moreover, a small distillation unit (following ASTM D-1160) was used to fractionate the hydrotreated oils showing complete deoxygenation, in order to investigate the concentration of nitrogen and its distribution in lower $\left(<340^{\circ} \mathrm{C}\right)$ and higher $\left(>340^{\circ} \mathrm{C}\right)$ fractional cuts. Comprehensive analysis on the upgraded fuel and distilled fractional cuts was carried out.

\section{Materials and Methods}

\subsection{Materials}

The biocrude used in this research was obtained from Aarhus University (Denmark), after the processing of Spirulina under sub-critical conditions at 220 bar and $350{ }^{\circ} \mathrm{C}$. In the framework of the HyFlexFuel project a pilot-scale continuous HTL facility was used to produce biocrude with a throughput of up to $100 \mathrm{~L} / \mathrm{h}$ [17]. Properties of the feedstock and HTL biocrude are listed in Table 1.

Table 1. Spirulina feedstock and HTL biocrude analysis. Elemental composition is expressed on dry basis and oxygen by difference.

\begin{tabular}{|c|c|c|c|c|c|c|c|c|}
\hline \multirow{2}{*}{ Materials } & \multicolumn{5}{|c|}{ Elemental Composition (wt. \%) } & \multirow{2}{*}{$\begin{array}{c}\text { HHV } \\
(\mathrm{MJ} / \mathrm{kg})\end{array}$} & \multirow{2}{*}{$\begin{array}{l}\text { Ash Content } \\
\text { (wt. \%) }\end{array}$} & \multirow{2}{*}{$\begin{array}{l}\text { Water Content } \\
\text { (wt. \%) }\end{array}$} \\
\hline & C & $\mathbf{H}$ & $\mathbf{N}$ & $S$ & $\mathrm{O}$ & & & \\
\hline Spirulina & 53.5 & 7.2 & 12.6 & - & 26.6 & 24.0 & 5.8 & 6.4 \\
\hline Biocrude & 78.1 & 10.4 & 8.0 & - & 3.5 & 38.0 & 0.2 & 3.8 \\
\hline
\end{tabular}

A pre-activated commercial Ni-Mo $/ \gamma-\mathrm{Al}_{2} \mathrm{O}_{3}$ hydrotreating catalyst in the form of extrudates was provided by Shell Denmark A/S. This pre-sulfided catalyst was activated at $340{ }^{\circ} \mathrm{C}$ and $60 \mathrm{bar}$ in the Shell refinery in Fredericia, Denmark.

\subsection{Experimental Methods}

\subsubsection{Design of Experiments}

In order to understand the most influential process parameters during hydrotreating, a factorial two-level experimental design with three factors on two levels $\left(2^{3}\right)$, as stated in Table 2, was used to investigate further [27].

Table 2. Test factors for hydrotreating experiments.

\begin{tabular}{ccccc}
\hline Factor & Name & Unit & Low Level (-) & High Level (+) \\
\hline $\mathrm{A}$ & Temperature & ${ }^{\circ} \mathrm{C}$ & 250 & 350 \\
$\mathrm{~B}$ & $\mathrm{H}_{2}$ pressure & bar & 40 & 80 \\
$\mathrm{C}$ & Residence time & $\mathrm{h}$ & 2 & 4 \\
\hline
\end{tabular}

The complete experimental matrix with obtained responses is given in Table 3.

Even though hydrotreating is affected by a large number of factors, during this study only reaction temperature, initial $\mathrm{H}_{2}$ pressure, and residence time were considered and thus, the oxygen and nitrogen contents were measured as response variables. 
Table 3. Two-level factorial experimental matrix (1-8) along with three confirmatory experiments (9-11) at high temperatures.

\begin{tabular}{cccc}
\hline Exp. & $\begin{array}{c}\text { Factor A } \\
\text { Temperature }\end{array}$ & $\begin{array}{c}\text { Factor B } \\
\text { Initial } \mathbf{H}_{\mathbf{2}} \text { Pressure }\end{array}$ & $\begin{array}{c}\text { Factor C } \\
\text { Reaction Time }\end{array}$ \\
\hline 1 & $250(-)$ & $40(-)$ & $2(-)$ \\
2 & $350(+)$ & $40(-)$ & $2(-)$ \\
3 & $250(-)$ & $40(-)$ & $4(+)$ \\
4 & $350(+)$ & $40(-)$ & $4(+)$ \\
5 & $250(-)$ & $80(+)$ & $2(-)$ \\
6 & $350(+)$ & $80(+)$ & $2(-)$ \\
7 & $250(-)$ & $80(+)$ & $4(+)$ \\
8 & $350(+)$ & $80(+)$ & $4(+)$ \\
9 & $375(+)$ & $70(+)$ & $3(+)$ \\
10 & $400(+)$ & $65(+)$ & $2.5(+)$ \\
11 & $400(+)$ & $70(+)$ & $2(-)$ \\
\hline
\end{tabular}

\subsubsection{Experimental Set-Up}

Hydrotreatment was carried out in a pair of $25 \mathrm{~mL}$ Swagelok micro-batch stainless steel reactors. To confirm reproducibility and comparability of results, experiments were carried out in duplicates. Each measured quantity was represented as the mean of the two independent experiments, with an error corresponding to their standard deviation. For each experiment, $4 \mathrm{~g}$ of biocrude were loaded inside the reactor, along with $2 \mathrm{~g}$ of pre-sulfided catalyst and three stainless steel spheres $(4 \mathrm{~mm}$ dia.) to enhance mixing. Both reactors were purged with $\mathrm{N}_{2}$ and $\mathrm{H}_{2}$ twice at 80 bar, leak tested and filled with a certain $\mathrm{H}_{2}$ pressure. In order to obtain high temperatures and efficient mixing a SBL-2D fluidized sand-bath (Techne, Stone, UK) and an agitation device with a frequency of $450 \mathrm{~min}^{-1}$ was used. Pressure was continuously measured with an A-10 pressure transducer (Wika, Klingenberg, Germany) and recorded in a data logger connected to a LabVIEW ${ }^{\mathrm{TM}}$ programme. After the desired reaction time, both reactors were quenched in a water bath prior to gas venting and product separation. The gas was released in the fume-hood and the hydrotreated liquid products were separated into oil phase and water phase, by centrifugation (6-16HS centrifuge, Sigma, Wem, UK) at $4000 \mathrm{rpm}$ for $5 \mathrm{~min}$.

\subsubsection{Fractional Distillation}

Selected samples of the produced oil underwent fractional distillation in a small unit, complying with ASTM D-1160 [28]. The set-up was bought from Ace Glass Inc. (Vineland, NJ, USA), and involves a $10 \mathrm{~mL}$ pot flask at the bottom of the distillation column along with three graduated distillation receiver tubes having a volume of $3 \mathrm{~mL}$ each. This unit is able to reach an operating pressure of $10 \mathrm{mbar}$ after connecting the vacuum pump to the top of the condenser. Water circulation in the distillation column was done at $5{ }^{\circ} \mathrm{C}$ by using a $200 \mathrm{~F}$ thermal circulation bath (Julabo, Seelbach, Germany) in order to achieve better condensation and to reduce losses in the cold trap. To provide adiabatic conditions and avoid heat losses the column was surrounded by a HS- $450{ }^{\circ} \mathrm{C} \mathrm{NiCr}$ heating cable from Horst $\mathrm{GmbH}$ (Lorsch, Germany) with a $4 \mathrm{~mm}$ winding radius. Furthermore, the heating tape was insulated from outside and K-type thermocouples were used to measure the vapor temperature and the column head skin temperature. To ensure the adiabatic conditions, the temperature of the heating cable has been kept $5-10{ }^{\circ} \mathrm{C}$ below vapor temperature. Pressure, vapor temperature, and pot flask skin temperature were continuously monitored, in order to obtain the desired fractional cuts (lower $\left(<340^{\circ} \mathrm{C}\right)$ and higher $\left.\left(>340^{\circ} \mathrm{C}\right)\right)$.

ASTM D-1160 was used as a guideline to produce fractions with a final cut temperature of $340{ }^{\circ} \mathrm{C}$, which lies up to diesel range [28]. To avoid cracking and thermal degradation of hydrotreated biocrude, due to the presence of possible heteroatoms, the pot flask temperature and skin temperature should not exceed $310^{\circ} \mathrm{C}$ [29]. Gasoline cut was attained and collected at $<190{ }^{\circ} \mathrm{C}$ under atmospheric conditions. Subsequently, the vacuum was lowered to $20 \mathrm{mbar}$ and the fractional cuts at $168^{\circ} \mathrm{C}$ and $203^{\circ} \mathrm{C}$ vapour 
temperature, corresponding to atmospheric equivalent temperature (AET) of jet fuel $\left(190-290^{\circ} \mathrm{C}\right.$ ) and diesel $\left(290-340{ }^{\circ} \mathrm{C}\right)$ were obtained. The observed column head temperature was converted into AET by using a relation described by Maxwell and Bonnel [30].

\subsection{Characterization and Analytical Techniques}

A 2400 Series II system CHN-O analyzer (ASTM D-5291) from Perkin Elmer (Waltham, MA, USA) with a detection limit of $100 \mathrm{ppm}$ was used to determine the elemental composition of the hydrotreated oil in terms of $\mathrm{C}, \mathrm{H}$, and N. Oxygen was calculated by difference. Furthermore, the degree of deoxygenation (de-O) and denitrogenation (de-N) was measured according to Equations (1) and (2):

$$
\begin{aligned}
& \text { de-O }=\left(1-\frac{\mathrm{O}_{\text {upgr.oil }}}{\mathrm{O}_{\text {biocrude }}}\right) \cdot 100 \\
& \text { de-N }=\left(1-\frac{\mathrm{N}_{\text {upgr.oil }}}{\mathrm{N}_{\text {biocrude }}}\right) \cdot 100
\end{aligned}
$$

The higher heating value (HHV) of the biocrudes and the upgraded samples was estimated through the correlation proposed by Channiwala and Parikh [31]:

$$
\mathrm{HHV}(\mathrm{MJ} / \mathrm{kg})=0.3491 \mathrm{C}+1.1783 \mathrm{H}+0.1005 \mathrm{~S}-0.1034 \mathrm{O}-0.0151 \mathrm{~N}-0.0211 \mathrm{~A}
$$

The ideal gas law was used to estimate the $\mathrm{H}_{2}$ consumption based on initial and final $\mathrm{H}_{2}$ pressure in the reactor, under the hypothesis of negligible production of other gases:

$$
\mathrm{n}_{\mathrm{H}_{2} \text { consumed }}=\frac{\mathrm{P}_{\text {initial }} \mathrm{V}}{\mathrm{RT}}-\frac{\mathrm{P}_{\text {final }} \mathrm{V}}{\mathrm{RT}}
$$

The boiling range distribution of biocrudes and upgraded oil was determined by means of simulated distillation (Sim-Dis) following ASTM D-7169 [32]. Sim-Dis was equipped with a Zebron ZB-1XT column by Phenomenex (Torrance, CA, USA), and a gas chromatography-flame ionization detector (GC-FID) from Shimadzu Corporation (Kyoto, Japan). To determine the chemical composition, the biocrude and the upgraded samples were analyzed by gas chromatography - mass spectrometry (GC-MS), utilizing a Trace 1300 ISQ QD-Single Quadrupole instrument (Thermo Scientific, Waltham, MA, USA) with a 40 to $300{ }^{\circ} \mathrm{C}$ temperature range as described previously [33].

\section{Results and Discussion}

Hereby, the hydrotreating of Spirulina biocrude is conducted as described in Section 2. The results of the single experiment are presented in terms of degree of deoxygenation (de-O), degree of denitrogenation (de-N), and hydrogen consumption as response variables. After the identification of influencing factors, the characterization of upgraded biocrude is discussed in terms of elemental composition, chemical structure and boiling point distribution.

\subsection{The Effect of the Process Parameters on Heteroatoms Removal}

In order to identify the most influencing parameters during hydrotreating, a two-level factorial design of experiments with varying reaction temperature, initial $\mathrm{H}_{2}$ pressure, and residence time was performed until experiment 8 as described in Table 3. To check the influence of these varying parameters on bio-oil properties, the effect and the interaction between each parameter have been calculated based on the elemental composition of the upgraded oil as shown in Table 4. Furthermore, the half-normal probability plot is used to assess which factors are important and which are of no significance. 
Table 4. Elemental composition (wt. \%) along with the obtained responses (de-O and de-N) and their calculated effects until experiment 8 . Oxygen is calculated by difference.

\begin{tabular}{|c|c|c|c|c|c|c|c|c|c|}
\hline Exp. & $\mathrm{C}$ & $\mathbf{H}$ & $\mathbf{N}$ & $\mathbf{O}$ & de-O [\%] & de-N [\%] & $\begin{array}{c}\mathrm{H}_{2} \text { Consumption } \\
{\left[\mathrm{kg}_{\mathrm{H} 2} / \mathrm{kg}_{\text {feed }}\right]}\end{array}$ & $\mathrm{H} / \mathrm{C}[-]$ & HHV [MJ/kg] \\
\hline Biocrude & $75.01 \pm 0.31$ & $10.40 \pm 0.09$ & $7.65 \pm 0.10$ & $6.94 \pm 0.12$ & - & - & - & $1.66 \pm 0.02$ & $37.59 \pm 0.20$ \\
\hline 1 & $76.94 \pm 0.49$ & $10.79 \pm 0.10$ & $7.19 \pm 0.05$ & $5.11 \pm 0.61$ & 26 & 6 & $0.0025 \pm 0.0002$ & $1.68 \pm 0.01$ & $38.93 \pm 0.21$ \\
\hline 2 & $81.24 \pm 0.12$ & $11.18 \pm 0.03$ & $5.55 \pm 0.04$ & $1.95 \pm 0.11$ & 72 & 27 & $0.0060 \pm 0.0001$ & $1.65 \pm 0.00$ & $41.24 \pm 0.06$ \\
\hline 3 & $77.72 \pm 0.10$ & $10.76 \pm 0.05$ & $6.53 \pm 0.05$ & $5.00 \pm 0.20$ & 28 & 15 & $0.0033 \pm 0.0005$ & $1.66 \pm 0.01$ & $39.18 \pm 0.07$ \\
\hline 4 & $82.24 \pm 0.22$ & $11.05 \pm 0.08$ & $5.44 \pm 0.04$ & $1.28 \pm 0.35$ & 82 & 29 & $0.0058 \pm 0.0008$ & $1.61 \pm 0.01$ & $41.51 \pm 0.14$ \\
\hline 5 & $77.16 \pm 0.19$ & $10.66 \pm 0.02$ & $6.66 \pm 0.50$ & $5.53 \pm 0.69$ & 24 & 10 & $0.0033 \pm 0.0002$ & $1.66 \pm 0.01$ & $37.59 \pm 0.04$ \\
\hline 6 & $82.62 \pm 0.17$ & $11.87 \pm 0.04$ & $4.35 \pm 0.12$ & $1.17 \pm 0.09$ & 83 & 43 & $0.0108 \pm 0.0001$ & $1.72 \pm 0.00$ & $42.64 \pm 0.09$ \\
\hline 7 & $76.82 \pm 0.03$ & $10.98 \pm 0.03$ & $6.36 \pm 0.03$ & $6.13 \pm 0.03$ & 12 & 17 & $0.0045 \pm 0.0003$ & $1.67 \pm 0.00$ & $38.68 \pm 0.04$ \\
\hline 8 & $84.31 \pm 0.35$ & $12.13 \pm 0.06$ & $4.03 \pm 0.17$ & $0.00 \pm 0.23$ & 100 & 47 & $0.0125 \pm 0.0002$ & $1.73 \pm 0.00$ & $43.70 \pm 0.16$ \\
\hline 9 & $84.55 \pm 0.16$ & $12.66 \pm 0.10$ & $3.09 \pm 0.05$ & $0.00 \pm 0.01$ & 100 & 60 & $0.0103 \pm 0.0001$ & $1.80 \pm 0.00$ & $44.38 \pm 0.17$ \\
\hline 10 & $84.17 \pm 0.02$ & $11.99 \pm 0.05$ & $3.84 \pm 0.11$ & $0.00 \pm 0.04$ & 100 & 50 & $0.0080 \pm 0.0002$ & $1.71 \pm 0.00$ & $43.45 \pm 0.06$ \\
\hline 11 & $84.37 \pm 0.11$ & $12.44 \pm 0.02$ & $3.19 \pm 0.04$ & $0.00 \pm 0.01$ & 100 & 58 & $0.0093 \pm 0.0002$ & $1.77 \pm 0.00$ & $44.05 \pm 0.06$ \\
\hline
\end{tabular}


Potential coke and product gases during hydrotreatment were considered negligible as compared to the losses during liquid (oil plus water) recovery in a micro-batch reactor. Thus, the overall yield (wt. \%) of upgraded oil is not reported in the present study in order not to present an inaccurate picture. Though, the liquid recovered was around $\sim 90 \mathrm{wt}$. $\% \pm 5$ during all experiments which is similar to other works in the literature, for example [21]. Current study focuses on the removal of heteroatoms $(\mathrm{O}$ and $\mathrm{N})$ by varying the initial $\mathrm{H}_{2}$ pressure and reaction time at considerably low operating temperatures $\left(250^{\circ} \mathrm{C}\right.$ and $\left.350{ }^{\circ} \mathrm{C}\right)$.

Table 4 shows intriguing results in case of heteroatom removal. Within the detection limit of $\mathrm{CHN} / \mathrm{O}, 100 \% \mathrm{O}$ content is removed from algal biocrude at $350{ }^{\circ} \mathrm{C}, 80 \mathrm{bar}$ and $4 \mathrm{~h}$ of reaction time. At these severe conditions of present experimental matrix $\mathrm{N}$ content is reduced up to $47 \%$. Till now, the most prominent studies on heteroatom removal by Elliott et al. [26], Biller et al. [21] and Bai et al. [23] showed the removal of $\mathrm{O}$ and $\mathrm{N}$ up to $\sim 90 \%$ and $\sim 99 \%$ respectively at $\sim 400{ }^{\circ} \mathrm{C}$.

Biller et al. [21] and Duan et al. [24] reported 91 and 90\% reduction of $\mathrm{O}$ along with 60 and $59 \%$ reduction of $\mathrm{N}$ at $405{ }^{\circ} \mathrm{C}$ and $400{ }^{\circ} \mathrm{C}$. Furthermore, Elliott et al. [26] was able to reduce final $\mathrm{O}$ and $\mathrm{N}$ levels down to $\sim 1$ and $~ 0.05 \mathrm{wt} . \%(99 \%)$ at $405{ }^{\circ} \mathrm{C}$ in a continuous flow catalytic fixed bed reactor. Lower denitrogenation rates until experiment 8 from the above study are evidence that high temperatures are vital for the removal of nitrogen. It also seems obvious, that mild conditions relating with each variable factor just slightly affect the $\mathrm{O}$ content, whereas the $\mathrm{N}$ content almost remain intact.

Based on this knowledge, a set of three confirmatory experiments (Exp. 9, 10 and 11) were performed as shown in Table 4 . They are based on the anticipation that $\mathrm{N}$ content will be further reduced with the $100 \%$ removal of $\mathrm{O}$ at high temperatures. Subsequently, the results presented in Table 4 show complete deoxygenation for experiments 9,10 and 11, while at best the denitrogenation was only achieved up to $60 \%$ at $375{ }^{\circ} \mathrm{C}$ and 70 bar initial $\mathrm{H}_{2}$ for three hours. However, $50 \%$ and $58 \%$ of denitrogenation is achieved at $400{ }^{\circ} \mathrm{C}$ by changing $\mathrm{H}_{2}$ pressure and reaction time.

The absolute values from Table 5 indicate the most relevant factors affecting the responses $\left(R_{1}\right.$ and $\mathrm{R}_{2}$ ). Moreover, half-normal probability graph as shown in Figure 1 is used to assess the significant and insignificant factors for de-O $\left(\mathrm{R}_{1}\right)$ and de- $\mathrm{N}\left(\mathrm{R}_{2}\right)$.

Table 5. Selected process parameters (factors) and their measured effects on de-O $\left(R_{1}\right)$ and de-N $\left(R_{2}\right)$ from experiments $1-8$.

\begin{tabular}{cccccccc}
\hline Effect & Factor A & Factor B & Factor C & Factor AB & Factor AC & Factor BC & Factor ABC \\
\hline Effect $\mathrm{R}_{1}[\%]$ & 64.24 & 3.51 & 6.50 & 14.63 & 10.06 & 0.88 & 6.03 \\
Effect $\mathrm{R}_{2}[\%]$ & 24.07 & 10.80 & 4.53 & 6.29 & -1.75 & -0.51 & 1.85 \\
\hline
\end{tabular}
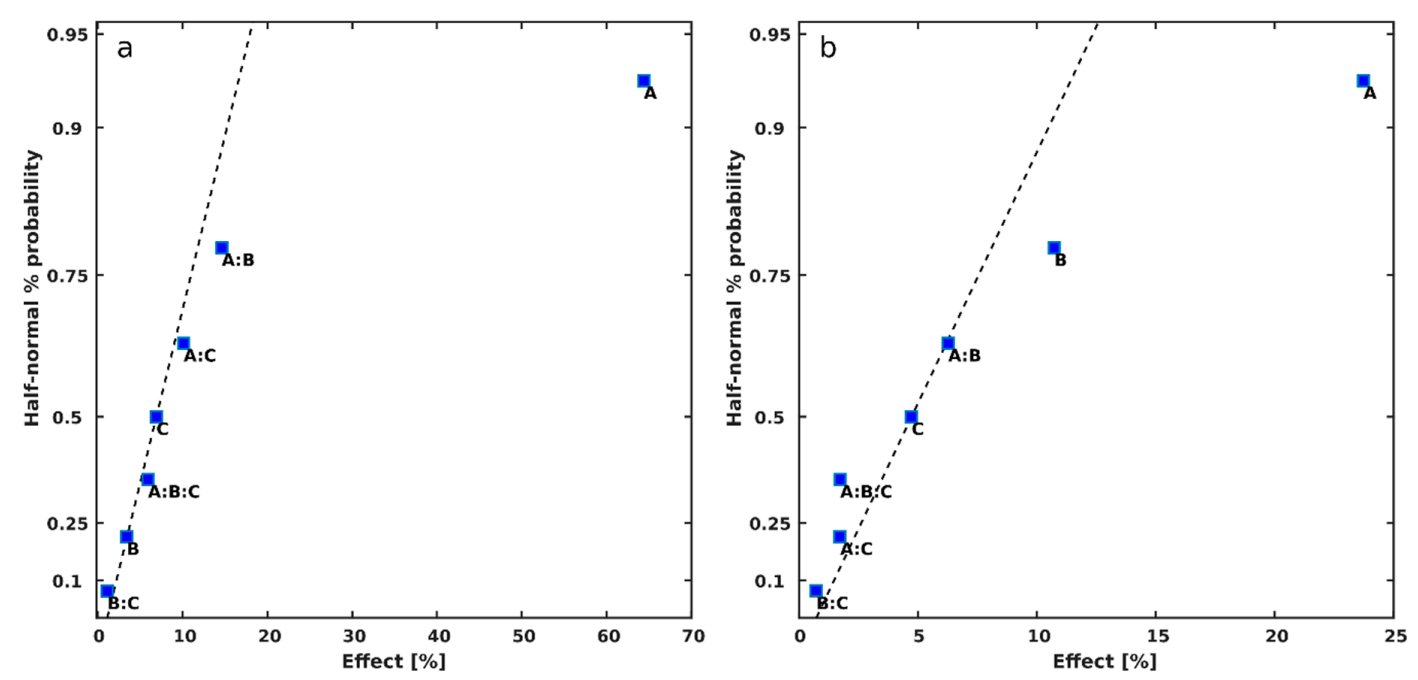

Figure 1. Half normal plot of effects [\%], de-O (a) and de-N (b). 
Assuming that the estimated effects of each factor and each interaction term on the de-O follow a normal distribution, the absolute estimated effects will then follow a half-normal distribution. By plotting the ranked estimated effects against the cumulative percent contribution (the contribution to the total sum of squares) of each factor, significant (and insignificant) factors can be identified. Insignificant factors are those having small estimated effects and tend to fall on a straight line starting at the origin $(0: 0)$.

From Figure 1a, it is clear that the only significant factor influencing the de-O is the temperature. Obviously, the half-normal plot show only positive effects (absolute estimated effects). By examining Table 4 it is evident that temperature indeed has a positive effect on the de-O. At the lower level temperature, the higher degree of deoxygenation obtained was $28 \%$ (Exp. 3), whereas the de-O range from $72-100 \%$ at the higher level. Likewise, a similar identification of the significant factors influencing the de-N can be observed in in Figure 1b. It is apparent that temperature is also significantly influencing the de- $\mathrm{N}$ along with the hydrogen pressure. Thus, the highest de-N was obtained in Exp. 8 (all factors set at high level) yielding a de-N of $47 \%$, which is only marginally higher than Exp. $6(\mathrm{de}-\mathrm{N}=43 \%)$ for which the reaction time was only $2 \mathrm{~h}$. As for the de-O, any interaction effects seem insignificant.

The hydrotreated oil after all 11 experiments has a higher $\mathrm{C}$ and a lower $\mathrm{O}$ and $\mathrm{N}$ content. However, $\mathrm{H} / \mathrm{C}$ molar ratio remains more or less stable with the algal biocrude at lower temperatures and lower pressures. While, at higher temperatures $\left(350-400{ }^{\circ} \mathrm{C}\right)$ and higher pressures ( 80 bar) overall $\mathrm{H} / \mathrm{C}$ molar ratio increases and thus the aromatics in the oil decreases. In addition, a negligible effect of reaction time is observed on the molar $\mathrm{H} / \mathrm{C}$ ratio. However, at $400{ }^{\circ} \mathrm{C}$ lower $\mathrm{H} / \mathrm{C}$ is observed as compared to $375^{\circ} \mathrm{C}$, which is anticipated as a result of cracking reaction. Subsequently, after the complete deoxygenation and $60 \%$ of $\mathrm{N}$ reduction the HHV increases from $37.6 \mathrm{MJ} / \mathrm{kg}$ of the algal biocrude to $44.4 \mathrm{MJ} / \mathrm{kg}$. Higher temperatures are needed for complete denitrogenation, but both $\mathrm{H} / \mathrm{C}$ and HHV decrease at higher temperature of $400^{\circ} \mathrm{C}$ in relation with $375{ }^{\circ} \mathrm{C}$, which means that we are getting higher degree of denitrogenation with a loss of fuel quality. This may be caused by the formation of coke, as HTL biocrude due to high polarity are unstable and prone toward the polymerization and deactivation of NiMo catalyst. This complete deoxygenated oil with reduced $\mathrm{N}$ content is considered more stable and thus reduces the possibility of catalyst deactivation during further upgrading for on-specification fuel.

\subsection{Analysis of the Up-Graded Oil}

Simulated distillation (Sim-Dis) was used to evaluate the boiling point distribution of the catalytically upgraded oil samples and then compared with the untreated biocrude. Five different boiling point ranges are defined and described as gasoline $\left(>190^{\circ} \mathrm{C}\right)$, jet fuel $\left(190-290{ }^{\circ} \mathrm{C}\right)$, diesel $\left(290-340{ }^{\circ} \mathrm{C}\right)$, vacuum gas oil $\left(340-538^{\circ} \mathrm{C}\right)$ and vacuum residue $\left(>538^{\circ} \mathrm{C}\right)$. Table 6 along with Figure 2 shows yield of different fractions and boiling point distribution of all the experiments with complete degree of deoxygenation along with the biocrude and experiment 1 with the lowest possible operating range $\left(250{ }^{\circ} \mathrm{C}, 40\right.$ bar $\mathrm{H}_{2}$ for $2 \mathrm{~h}$ ). The biocrude shows large fractions in high molecular weight compounds and therefore, it associates with the higher residual cuts $\left(72.7 \%\right.$ above $\left.340{ }^{\circ} \mathrm{C}\right)$. In addition, the overall recovery at $720{ }^{\circ} \mathrm{C}$ increases from $72 \%$ to $92 \%$, thus the amount of potential distillable products also increases. Furthermore, after 100\% HDO more than $32 \%$ and $14 \%$ oil is in jet fuel and diesel range and around $15 \%$ is confined in residue. High temperatures and high initial $\mathrm{H}_{2}$ pressures are vital for the cracking of biocrude into lower fractional cuts. Present study shows that at $350{ }^{\circ} \mathrm{C}$ and 80 bar initial $\mathrm{H}_{2}$ pressure highest boiling point distribution above diesel is obtained with minimum residual fraction cut of $12.5 \%$. This looks very promising as by just tuning operating conditions at mild temperature $\left(350{ }^{\circ} \mathrm{C}\right)$ high production of diesel drop-in fuel could be achieved (Table 6 and Figure 2). 
Table 6. Sim-Dis analysis of biocrude and selected hydrotreated samples.

\begin{tabular}{cccccccc}
\hline \multirow{2}{*}{ Fractional Cuts } & \multirow{2}{*}{ Boiling Point Range } & \multicolumn{5}{c}{ Composition [wt. \%] } \\
\cline { 3 - 8 } & & Biocrude & Exp. 1 & Exp. 8 & Exp. 9 & Exp. 10 & Exp. 11 \\
\hline Gasoline & $<190^{\circ} \mathrm{C}$ & 3.9 & 3 & 13.1 & 4.8 & 5.6 & 7.9 \\
Jet fuel & $190-290^{\circ} \mathrm{C}$ & 14.5 & 15.5 & 32.2 & 33.4 & 34 & 34.5 \\
Diesel & $290-340^{\circ} \mathrm{C}$ & 8.9 & 8.5 & 18.4 & 15.3 & 13.6 & 14.5 \\
Vacuum gas oil & $340-538^{\circ} \mathrm{C}$ & 38.9 & 34.7 & 23.8 & 29 & 26.3 & 27.5 \\
Vacuum residue & $>538^{\circ} \mathrm{C}$ & 33.8 & 38.3 & 12.5 & 17.5 & 20.5 & 15.6 \\
\hline
\end{tabular}

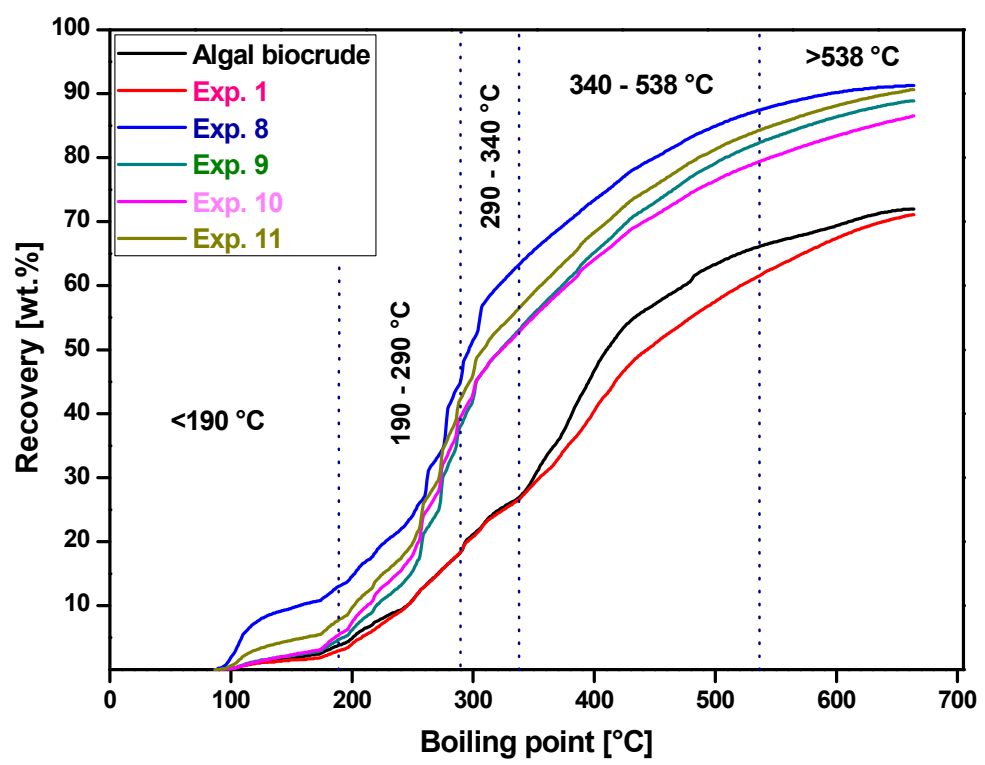

Figure 2. Boiling point distribution of biocrude and upgraded oil samples, obtained by simulated distillation.

Figure 3a,b show the GC-MS chromatograms of the HTL biocrude and the complete deoxygenated oils at $350{ }^{\circ} \mathrm{C}(47 \% \mathrm{HDN})$.

The untreated biocrude (Figure 3a) shows a complex mixture of numerous different hydrocarbons and heteroatoms (mainly $\mathrm{O}$ and $\mathrm{N}$ ), as expected from the elemental analysis. The oxygen containing compounds are mainly saturated fatty acids (hexadecanoic acid) and phenol derivatives such as p- and m-cresol. Moreover, fatty alcohols such as dodecanol are also observed in small amounts. Whereas, nitrogen-containing compounds are mostly found in the form of non-heterocyclic high molecular weight compounds such as various amides. However, $\mathrm{N}$ compounds are also present in the form of ring type structures with either one $\mathrm{N}$ atom, such as indoles and pyrroles, or two $\mathrm{N}$ atoms, such as pyrazines. The sole purpose of hydrotreating is to convert heteroatoms into their respective hydrocarbons along with the saturation of double bonds and cracking of high molecular weight compounds. Figure $3 \mathrm{~b}$ shows a chromatogram of upgraded oil (Exp. 8) after the complete removal of $\mathrm{O}$ atoms at $350{ }^{\circ} \mathrm{C}$ and reveals the presence of dominating aliphatic hydrocarbons ranging from $\mathrm{C}_{14}$ to $\mathrm{C}_{21}$. Aromatic hydrocarbons such as ethylbenzene and toluene are also present in the upgraded oil. At the same time, $\mathrm{N}$ is observed in the GC-MS spectrum, such as the presence of amides in Figure $3 \mathrm{~b}$ at the retention time of $25.51 \mathrm{~min}$ and $27.09 \mathrm{~min}$. However, the GC-MS spectrum also indicates minor presence of amine, indole, nitrile, pyrrole, pyrazine, pyridine and quinoline in the hydrotreated oil. 

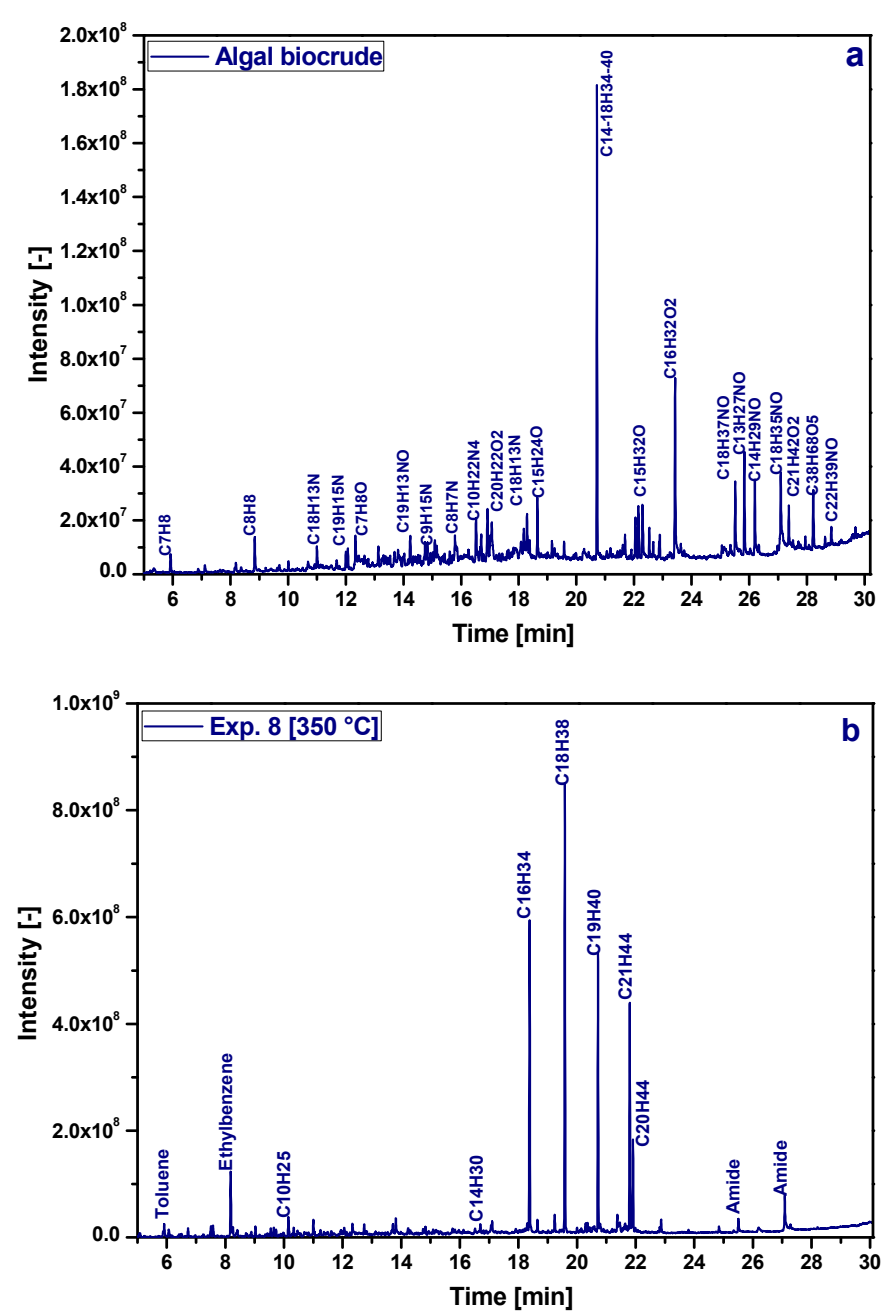

Figure 3. GC-MS chromatographs of (a) bio crude and (b) Experiment 8 at $350{ }^{\circ} \mathrm{C}$.

\subsection{Distribution of Nitrogen-Containing Compounds}

GC-MS analysis is only able to investigate the volatile fraction of the sample, hence it does not account for all molecules in the oil. Therefore, in order to assess the distribution of $\mathrm{N}$ content in the light and heavy fractional cuts of the upgraded oil, a more relevant industrial approach following ASTM D-1160 is carried out. Biller et al. [21] reported inappreciable amounts of nitrogen-containing compounds through GC-MS; while, through elemental analysis they observed $1-1.5 \%$ of $\mathrm{O}$ and $2.4-2.7 \%$ of $\mathrm{N}$. They performed $\mathrm{C}_{5}$ (pentane) extraction of hydrotreated oil to investigate the distribution of $\mathrm{O}$ and $\mathrm{N}$ between $\mathrm{C}_{5}$ soluble (flowable) and $\mathrm{C}_{5}$ insoluble (asphaltene) fractions. They were able to completely remove $\mathrm{O}$ content in $\mathrm{C}_{5}$ soluble fraction, but the removal of $\mathrm{N}$ content was not satisfactory and it seems that it was almost homogenously distributed in $\mathrm{C}_{5}$ soluble and insoluble fractions.

In order to determine the distribution of $\mathrm{N}$ content in lower and higher molecular weight compounds, the hydrotreated oil from experiments 8 (47\% HDN) and $9(60 \% \mathrm{HDN})$ were subjected to further investigation. Consequently, we performed true boiling point distillation following ASTM D-1160 to assess the concentration and the distribution of heteroatom content in low and high molecular weight fuel fractional cuts which correspond up to diesel $\left(<340{ }^{\circ} \mathrm{C}\right)$ and vacuum residue $\left(>340{ }^{\circ} \mathrm{C}\right)$. Results are shown in Table 7. 
Table 7. Yields (\%) and elemental analysis ( $\mathrm{N}$ and $\mathrm{O}$ content in wt. \%), H/C and N/C molar ratios of below and above diesel range fraction cuts.

\begin{tabular}{|c|c|c|c|c|c|c|c|c|c|c|}
\hline \multirow[b]{2}{*}{ Exp. } & \multicolumn{5}{|c|}{ Light Fraction $\left(<340^{\circ} \mathrm{C}\right)$} & \multicolumn{5}{|c|}{ Heavy Fraction $\left(>340^{\circ} \mathrm{C}\right)$} \\
\hline & $\begin{array}{l}\text { Yield } \\
\text { [wt. \%] }\end{array}$ & $\begin{array}{c}\mathbf{N} \\
\text { [wt. \%] }\end{array}$ & $\begin{array}{c}\mathrm{O} \\
\text { [wt. \%] }\end{array}$ & $\begin{array}{c}\mathrm{H} / \mathrm{C} \\
{[-]}\end{array}$ & $\begin{array}{c}\text { N/C } \\
{[-]}\end{array}$ & $\begin{array}{c}\text { Yield } \\
\text { [wt. \%] }\end{array}$ & $\begin{array}{c}\mathrm{N} \\
\text { [wt. \%] }\end{array}$ & $\begin{array}{c}\mathrm{O} \\
\text { [wt. \%] }\end{array}$ & $\begin{array}{c}\mathrm{H} / \mathrm{C} \\
{[-]}\end{array}$ & $\begin{array}{c}\text { N/C } \\
{[-]}\end{array}$ \\
\hline 8 & 52 & 1.30 & 0 & 1.86 & 0.02 & 35 & 2.73 & 0.08 & 1.48 & 0.03 \\
\hline 9 & 29 & 1.15 & 0 & 1.82 & 1.32 & 47 & 1.95 & 0.24 & 1.32 & 0.02 \\
\hline
\end{tabular}

Table 7 shows, that $32 \%$ and $37 \%$ of $\mathrm{N}$ content is concentrated in the light fraction while vacuum residue contains $68 \%$ and $63 \%$ of $\mathrm{N}$ content for experiments 8 and 9 , respectively. These results reveal that most of the nitrogen-containing compounds are distributed in the higher fractional cuts. Additionally, no $\mathrm{O}$ content is associated with the light fraction for both experiments while, $0.24 \mathrm{wt}$ \% of $\mathrm{O}$ and $0.08 \mathrm{wt}$. \% of $\mathrm{O}$ is incorporated in the vacuum residue obtained after the fractional distillation of experiments 8 and 9 respectively. The results indicate that oxygen is in fact concentrated in the heavy fraction, although in small amount. This means that when analyzing the total sample it is diluted to below the error associated with the $\mathrm{CHN}$ analyzer and therefore reported as zero. The presence of 0.08 wt. $\%$ of $\mathrm{O}$ in vacuum residue of hydrotreated oil $\left(375^{\circ} \mathrm{C}\right)$ as compared to the $0.24 \mathrm{wt} . \%$ of $\mathrm{O}$ $\left(350^{\circ} \mathrm{C}\right)$ also validate the statistical analysis, which showed that temperature is a main driver for $\mathrm{O}$ removal. Moreover, overall higher $\mathrm{H} / \mathrm{C}$ molar ratio is observed for diesel range $(>1.82)$ and very low $\mathrm{H} / \mathrm{C}$ molar ratio $(<1.48)$ was observed for vacuum residue in case of both experiment.

Figure 4 illustrates a modified Van Krevelen plot as a function of $\mathrm{H} / \mathrm{C}$ and N/C molar ratio for biocrude, hydrotreating experiments and distillation cut of upgraded oil from experiments 8 and 9 . Starting from the same biomass composition, it is clear that both temperature and pressure have a significant effect on the removal of $\mathrm{N}$ heteroatoms. Thus, the N/C molar ratio decreases along with the increase of hydrocarbon content. This plot also elucidates the distribution of nitrogen-containing compounds in lower and higher fractional cuts for experiments 8 and 9; and shows that the N/C molar ratio decreases in the hydrocarbon range (higher $\mathrm{H} / \mathrm{C}$ molar ratio) but on the other hand $\mathrm{N} / \mathrm{C}$ molar ratio increases as the aromatic content of the fractional cut increases.

Furthermore, the yields of the small fractional distillation unit are also stated in Table 7. $2.76 \mathrm{~g}$ and $1.09 \mathrm{~g}$ of sample is used for the fractional distillation of experiments 8 and 9, respectively. Higher recovery of $87 \mathrm{wt}$. \% is obtained after the fractional distillation of experiment 8 as compared to $76 \mathrm{wt}$. \% for experiment 9. Vacuum residue cut for both experiments is in line with the Sim-Dis results. However, some losses in the light fractional cut $\left(<340{ }^{\circ} \mathrm{C}\right)$ were observed after comparing it with Sim-Dis results, which may be due to the loss of lighter fraction in the distillation column and column head. From experiment 8 it is clear that the losses are less as compared to experiment 9 due to the use of higher amount of sample. Losses for lighter fractional cuts could be minimized by subjecting higher amount of sample to the fractional distillation unit.

Even though nitrogen-containing compounds are mostly found in the higher fractional cuts $\left(>340{ }^{\circ} \mathrm{C}\right)$, still some nitrogen is found in the light fraction. Therefore, this could not be used directly as a fuel, because of the indirect regulations applied on the fuel specification due to the presence of $\mathrm{N}$ compounds. The reason for the presence of remaining $\mathrm{N}$ compounds could be found in thermodynamics and the reduction of partial $\mathrm{H}_{2}$ pressure during hydrotreating. Thus, we suggest that hydrotreating of algal biocrude for the removal of heteroatom $\mathrm{N}$ either possibly requires higher temperatures (which will result in reduced yields due to the formation of volatiles) or multi-stage catalytic treatment, to partially stabilize the oil before further upgrading at higher temperatures in order to completely remove nitrogen-containing compounds. 


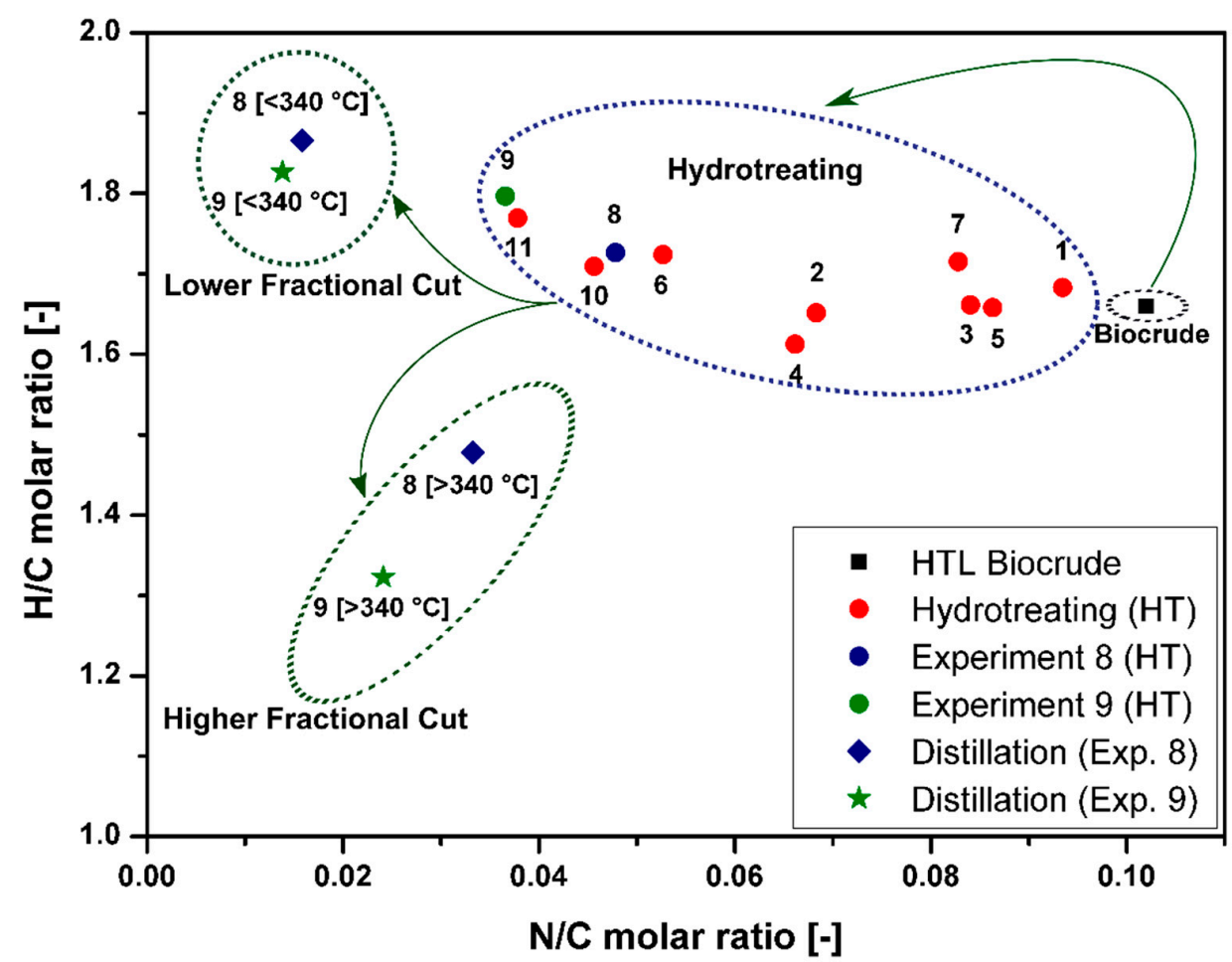

Figure 4. Modified Van Krevelen diagram showing molar ratio of $\mathrm{H} / \mathrm{C}$ as a function of N/C for Spirulina feedstock, HTL biocrude, 11 hydrotreating experiments and fractional distillation cuts of experiment 8 and 9 .

\section{Conclusions}

The most influential parameters affecting the hydrotreating of Spirulina (microalgae) biocrude were successfully identified. In addition, the distribution of heteroatoms in lower and higher fractional cuts was explored by using a small fractional distillation unit following the ASTM D-1160. For this purpose, a parametric study following a factorial two-level experimental design with three subsequent confirmatory experiments was carried out in a micro-batch reactor using conventional $\mathrm{NiMo} / \mathrm{Al}_{2} \mathrm{O}_{3}$ catalyst. Operating temperature has a key influence on the degree of deoxygenation (de-O), whereas the operating pressure along with temperature-pressure interaction mainly affects the degree of denitrogenation (de-N). Complete deoxygenation of upgraded free flowing oil was observed at $350{ }^{\circ} \mathrm{C}$. An optimized experiment at $375{ }^{\circ} \mathrm{C}, 70$ bar initial $\mathrm{H}_{2}$ and $3 \mathrm{~h}$ residence time leads toward $100 \%$ de-O, $60 \%$ de-N, $1.80 \mathrm{H} / \mathrm{C}$ ratio and a maximum $\mathrm{HHV}$ of $44.38 \mathrm{MJ} / \mathrm{kg}$. In addition, fractional distillation up to diesel $\left(<340^{\circ} \mathrm{C}\right)$ and vacuum residue $\left(>340^{\circ} \mathrm{C}\right)$ cut shows a significant concentration of $63-68 \%$ of $\mathrm{N}$ content in the higher fractional cut. Emanating from these encouraging results, shows that oxygen could be completely removed from given biocrude with a high liquid recovery.

Author Contributions: The authors have equally contributed to the writing of the manuscript.

Funding: This project has received funding from the European Union's Horizon 2020 research and innovation programme under grant agreement No 764734.

Conflicts of Interest: The authors declare no conflict of interests.

\section{References}

1. World Energy Outlook; International Energy Agency: Paris, France, 2017. Available online: https://webstore. iea.org/world-energy-outlook-2017 (accessed on 14 November 2018).

2. Doornbosch, R.; Steenblik, R. Biofuels: Is the Cure Worse Than the Disease? Available online: https: / / www.oecd.org/sd-roundtable/papersandpublications/39348696.pdf (accessed on 13 July 2018). 
3. Sims, R.E.H.; Mabee, W.; Saddler, J.N.; Taylor, M. An overview of second generation biofuel technologies. Bioresour. Technol. 2010, 101, 1570-1580. [CrossRef] [PubMed]

4. Alam, F.; Mobin, S.; Chowdhury, H. Third generation biofuel from Algae. Procedia Eng. 2015, 105, 763-768. [CrossRef]

5. Chisti, Y. Biodiesel from microalgae. Biotechnol. Adv. 2007, 25, 294-306. [CrossRef] [PubMed]

6. Molino, A.; Iovine, A.; Casella, P.; Mehariya, S.; Chianese, S.; Cerbone, A.; Rimauro, J.; Musmarra, D. Microalgae Characterization for Consolidated and New Application in Human Food, Animal Feed and Nutraceuticals. Int. J. Environ. Res. Public Health 2018, 15, 2436. [CrossRef] [PubMed]

7. Biller, P.; Ross, A.B. Potential yields and properties of oil from the hydrothermal liquefaction of microalgae with different biochemical content. Bioresour. Technol. 2011, 102, 215-225. [CrossRef] [PubMed]

8. Singh, N.K.; Dhar, D.W. Microalgae as second generation biofuel. A review. Agron. Sustain. Dev. 2011, 31, 605-629. [CrossRef]

9. Pienkos, P.T.; Darzins, A. The promise and challenges of microalgal-derived biofuels. Biofuels Bioprod. Biorefin. 2009, 3, 431-440. [CrossRef]

10. Peterson, A.A.; Vogel, F.; Lachance, R.P.; Fröling, M.; Michael, J.A.; Tester, J.W. Thermochemical biofuel production in hydrothermal media: A review of sub- and supercritical water technologies. Energy Environ. Sci. 2008, 1, 32-65. [CrossRef]

11. Toor, S.S.; Rosendahl, L.; Rudolf, A. Hydrothermal liquefaction of biomass: A review of subcritical water technologies. Energy 2011, 36, 2328-2342. [CrossRef]

12. Ramirez, A.J.; Brown, J.R.; Rainey, J.T. A Review of Hydrothermal Liquefaction Bio-Crude Properties and Prospects for Upgrading to Transportation Fuels. Energies 2015, 8, 6765-6794. [CrossRef]

13. Frank, E.D.; Elgowainy, A.; Han, J.; Wang, Z. Life cycle comparison of hydrothermal liquefaction and lipid extraction pathways to renewable diesel from algae. Mitig. Adapt. Strateg. Glob. Chang. 2013, 18, 137-158. [CrossRef]

14. Liu, X.; Saydah, B.; Eranki, P.; Colosi, L.M.; Mitchell, B.G.; Rhodes, J.; Clarens, A.F. Pilot-scale data provide enhanced estimates of the life cycle energy and emissions profile of algae biofuels produced via hydrothermal liquefaction. Bioresour. Technol. 2013, 148, 163-171. [CrossRef] [PubMed]

15. Jones, S.; Zhu, Y.; Anderson, D.; Hallen, R.; Elliott, D.; Schmidt, A.; Albrecth, K.; Hart, T.; Butcher, M.; Drennan, C.; et al. Process Design and Economics for the Conversion of Algal Biomass to Hydrocarbons: Whole Algae Hydrothermal Liquefaction and Upgrading; Report No. PNNL-23227; Pacific Northest National Laboratory: Richland, WA, USA, 2014.

16. Pedersen, T.H.; Hansen, N.H.; Pérez, O.M.; Cabezas, D.E.V.; Rosendahl, L.A. Renewable hydrocarbon fuels from hydrothermal liquefaction: A techno-economic analysis. Biofuels Bioprod. Biorefin. 2018, 12, $213-223$. [CrossRef]

17. Anastasakis, K.; Biller, P.; Madsen, R.; Glasius, M.; Johannsen, I.; Anastasakis, K.; Biller, P.; Madsen, R.B.; Glasius, M.; Johannsen, I. Continuous Hydrothermal Liquefaction of Biomass in a Novel Pilot Plant with Heat Recovery and Hydraulic Oscillation. Energies 2018, 11, 2695. [CrossRef]

18. Jensen, C.U.; Guerrero, J.K.R.; Karatzos, S.; Olofsson, G.; Iversen, S.B. Fundamentals of Hydrofaction ${ }^{\mathrm{TM}}$ : Renewable crude oil from woody biomass, Biomass Convers. Biorefinery 2017, 7, 495-509.

19. Duan, P.; Savage, P.E. Hydrothermal Liquefaction of a Microalga with Heterogeneous Catalysts. Ind. Eng. Chem. Res. 2011, 50, 52-61. [CrossRef]

20. Ross, A.B.; Biller, P.; Kubacki, M.L.; Li, H.; Lea-Langton, A.; Jones, J.M. Hydrothermal processing of microalgae using alkali and organic acids. Fuel 2010, 89, 2234-2243. [CrossRef]

21. Biller, P.; Sharma, B.K.; Kunwar, B.; Ross, A.B. Hydroprocessing of bio-crude from continuous hydrothermal liquefaction of microalgae. Fuel 2015, 159, 197-205. [CrossRef]

22. Huber, G.W.; Corma, A. Synergies between bio- and oil refineries for the production of fuels from biomass. Angew. Chem. Int. Ed. Engl. 2007, 46, 7184-7201. [CrossRef] [PubMed]

23. Bai, X.; Duan, P.; Xu, Y.; Zhang, A.; Savage, P.E. Hydrothermal catalytic processing of pretreated algal oil: A catalyst screening study. Fuel 2014, 120, 141-149. [CrossRef]

24. Duan, P.; Wang, B.; Xu, Y. Catalytic hydrothermal upgrading of crude bio-oils produced from different thermo-chemical conversion routes of microalgae. Bioresour. Technol. 2015, 186, 58-66. [CrossRef] [PubMed]

25. Li, Z.; Savage, P.E. Feedstocks for fuels and chemicals from algae: Treatment of crude bio-oil over HZSM-5. Algal Res. 2013, 2, 154-163. [CrossRef] 
26. Elliott, D.C.; Hart, T.R.; Schmidt, A.J.; Neuenschwander, G.G.; Rotness, L.J.; Olarte, M.V.; Zacher, A.H.; Albrecht, K.O.; Hallen, R.T.; Holladay, J.E. Process development for hydrothermal liquefaction of algae feedstocks in a continuous-flow reactor. Algal Res. 2013, 2, 445-454. [CrossRef]

27. Montgomery, D.C. Design and Analysis of Experiments, 8th ed.; John Wiley Sons: Singapore, 2012.

28. ASTM International. ASTM D1160, Standard Test Method for Distillation of Petroleum Products at Reduced Pressure; ASTM International: West Conshohocken, PA, USA, 2015.

29. ASTM International. ASTM D2892, Standard Test Method for Distillation of Crude Petroleum (15- Theoretical Plate Column); ASTM International: West Conshohocken, PA, USA, 2005.

30. Maxwell, J.B.; Bonnell, L.S. Derivation and Precision of a New Vapor Pressure Correlation for Petroleum Hydrocarbons. Ind. Eng. Chem. 1957, 49, 1187-1196. [CrossRef]

31. Channiwala, S.A.; Parikh, P.P. A unified correlation for estimating HHV of solid, liquid and gaseous fuels. Fuel 2002, 81, 1051-1063. [CrossRef]

32. ASTM International. ASTM D7169, Standard Test Method for Boiling Point Distribution of Samples with Residues Such as Crude Oils and Atmospheric and Vacuum Residues by High Temperature Gas Chromatography; ASTM International: West Conshohocken, PA, USA, 2011.

33. Pedersen, T.H.; Jensen, C.U.; Sandström, L.; Rosendahl, L.A. Full characterization of compounds obtained from fractional distillation and upgrading of a HTL biocrude. Appl. Energy 2017, 202, 408-419. [CrossRef]

(c) 2018 by the authors. Licensee MDPI, Basel, Switzerland. This article is an open access article distributed under the terms and conditions of the Creative Commons Attribution (CC BY) license (http://creativecommons.org/licenses/by/4.0/). 